\title{
Using a supply chain analysis to assess the sustainability of farm-to-institution programs
}

\author{
Gail Feenstra, ${ }^{1}$ Patricia Allen, ${ }^{2}$ Shermain Hardesty, ${ }^{3}$ Jeri Ohmart, ${ }^{4}$ and Jan Perez ${ }^{2}$
}

Submitted 14 February 2011 / Accepted 2 May 2011 / Published online 15 July 2011

Citation: Feenstra, G., Allen, P., Hardesty, S., Ohmart, J., \& Perez, J. (2011). Using a supply chain analysis to assess the sustainability of farm-to-institution programs. Journal of Agriculture, Food Systems, and Community Development, 1(4), 69-85. http://dx.doi.org/10.5304/jafscd.2011.014.009

Copyright (C) 2011 by New Leaf Associates, Inc.

\begin{abstract}
Interest in local and sustainable food among colleges and universities has risen considerably in the last decade. This study focuses on how to foster farm-to-institution programs by exploring barriers, opportunities, and potential solutions from different perspectives in the supply chain. We use a values-based supply chain approach to see what unique insights can be offered to people

${ }^{1}$ Corresponding author: Gail Feenstra, Agricultural Sustainability Institute/Sustainable Agriculture Research and Education Program, 1 Shields Avenue, University of California, Davis, CA 95616 USA; +1-530-752-8408; gwfeenstra@ucdavis.edu

${ }^{2}$ Center for Agroecology and Sustainable Food Systems, University of California, Santa Cruz, 1156 High Street, Santa Cruz, CA 95064 USA

${ }^{3}$ Department of Agricultural and Resource Economics, 1 Shields Avenue, University of California, Davis, CA 95616 USA; shermain@primal.ucdavis.edu

4 ASI/SAREP, 1 Shields Avenue, University of California, Davis, CA 95616 USA; jlohmart@ucdavis.edu

This project was supported by the National Research Initiative of the USDA Cooperative State Research, Education and Extension Service, grant number \#2006-55618-17015.
\end{abstract}

developing and maintaining these programs. Three research methods - a national survey of college students, a survey of institutional food service buyers in California, and in-depth interviews of people in the California distribution system, including farmers, distributors, and food service buyers - are used to collect data and perspectives from throughout the supply chain. Using the concepts from supply chain literature of product flows, financial flows, and information flows, we highlight key insights for various participants in the supply chain. Strengthening information flows and building relationships that allow all parties to build trust over time emerged as one of the most important elements in the success of these valuesbased supply chains. Educational institutions and the media can support these chains by becoming the vehicles for ongoing exchange of information among supply chain partners and the public.

\section{Keywords}

farm-to-institution, local food, supply chain, sustainability, values-based supply chain

\section{Introduction}

Interest in local and sustainable food among colleges and universities has risen considerably in 
the last five to 10 years. While there used to be very few, there are now 164 farm-to-college programs listed on the Community Food Security Coalition's Farm to College website (http://www.farmtocollege.org). This growth means a larger market share for local farm products. Purchasing local, sustainable foods produced by small and midscale producers is a value that institutional food service buyers are now seeking to embrace. Many of these buyers view changing their procurement strategies as an opportunity to support local suppliers and to educate students about the food system and health.

However, significant economic and infrastructural barriers stand in the way of rapidly and easily expanding these local food programs. The problems of locating suppliers, delivery and distribution mechanisms, and reliability have been identified as key barriers to accessing, purchasing, and serving local foods in institutional cafeterias (Murray, 2005; Vogt \& Kaiser, 2008). In addition, food service directors also cite problems such as lack of yearround availability, adequate quantity and quality of local products, and local and state regulations (Gregoire \& Strohbehn, 2002; Gregoire, Strohbehn, Huss, Huber, Karp, \& Klein, 2000). Colleges with buying programs for locally grown produce incur significant transaction costs, as well as pay premium prices (Hardesty, 2008). From the growers' perspective, obstacles include lack of product availability, lack of a dependable market, and the inability to change prices they receive (Gregoire, Arendt, \& Strohbehn, 2005).

Although these barriers have been explored, few researchers have looked across the supply chain to better understand the dynamics and linkages in order to create effective farm-to-institution projects. Researchers who have surveyed institutional buyers as well as farmers (Starr et al., 2003) and distributors (Bloom \& Hinrichs, 2010; Izumi, Alaimo, \& Hamm, 2010; Izumi, Wright, \& Hamm, 2009) found that prices high enough to satisfy producers while also affordable for buyers, seasonality, and availability of regional produce when buyers wanted it were challenges across the supply chain. Suggestions for improving supply chain linkages included encouraging farmers to show buyers the quality of products and services they can provide, and utilizing more mid-tier regional distributors in farm-to-institution transactions. Research on colleges and universities that explores barriers, opportunities, and potential solutions to enhance producer-institutional arrangements from multiple perspectives across the supply chain has been limited to date, but is gaining increased interest.

Our research on this topic starts from the premise that exploring the attitudes and behaviors of a variety of participants throughout the supply chain, from "farm to fork," will provide insights on how to create and sustain farm-to-institution programs. The consumption-oriented value-chain approach described by Hawkes (2009) provides an undergirding systems orientation for our study. Hawkes writes, "The underlying concept is that it is only by mapping the whole chain, and understanding the interactions within that chain as a system, that the most effective leverage points can be identified" ( $p$. 338). Accordingly, our paper approaches the system as an interconnected whole rather than as a collection of independent sectors, such as consumers, distributors, and buyers. Through quantitative surveys and qualitative in-depth interviews, we identify gaps and leverage points throughout the supply chain for expanding and improving farm-toinstitutions programs.

\section{Previous Supply/Value Chain Research}

The traditional supply chain for obtaining produce in institutions is fairly linear. After produce leaves the farm, it often goes through packer/shippers and sometimes processors before it ends up with wholesale distributors. Wholesale distributors for produce vary in size from small or medium-sized regional produce distributors to much larger broadline distributors ${ }^{1}$ who often carry a wide variety of products in addition to produce. In a conventional distribution system, attaining efficiencies and economies of scale are key strategies to minimizing

\footnotetext{
${ }^{1}$ A food-service broadline distributor carries a full line of products, including dry grocery, frozen, tabletop, equipment, and supplies. Many broadliners also carry perishable items such as meat, dairy, and produce.
} 
prices paid by the end consumer. Many distributors offer rebates to institutions that meet specified purchasing volumes; these incentives serve to discourage institutions from purchasing from multiple sources. It is also logistically convenient for buyers to aggregate purchases. Therefore, traditional supply chain research has focused on increasing efficiencies and decreasing price points.

\section{Value Chains and Values-Based Supply Chain Research}

As the demand for producing, distributing, and purchasing more foods identified with values of "local" or "regional," "sustainable," "family farmed," and "organic" has increased, the concept of "values-based supply chains" has emerged. These chains are different from traditional supply chains in that they attempt to enhance small and midscale farmers' financial viability by capturing price premiums in the marketplace for the environmental and social benefits (values) embedded in the products. They require that all partners in the chain work together to optimize value for everyone, including fair profit margins for producers and fair wages for their workers. Finally, in this system, partners maintain transparency throughout the supply chain by sharing information at each stage of the chain (Stevenson \& Pirog, 2008).

Applied research (Vogt \& Kaiser, 2008) has begun exploring the nature of emerging supply chains that can deliver products with these values and with their source information conveyed transparently to the end buyers (institutions, consumers). Various models help describe the structures and processes involved in what is ultimately available for consumers. By studying how particular chains function in the U.S. by doing case studies of poultry and tomatoes, Gereffi, Lee, and Christian (2009) note several important characteristics of the current food system. The one most relevant for us is that efficiency concerns have resulted in significant industrial consolidation in the food system, and smaller firms have been especially affected. Consolidation in the produce industry is an important background reality that influences how produce supply chains function.
Hawkes (2009) has explored a food supply chain system to understand how foods valued as healthier and more sustainable can be made available to consumers. Her "consumption-oriented food supply chain analysis" helps us identify what changes are needed in the entire supply chain to create healthier food environments. Since organizational, financial, technological, and policy incentives and disincentives affect food supply chain participants and offer leverage points for change, understanding more about these would allow us to identify bottlenecks and provide insights on how to increase healthful foods. Although our study uses a different methodological approach, focusing more on an "actor-based" food supply chain vs. a "process-based" food supply chain, we identify incentives and disincentives similar to those used by Hawkes..

The research approaches that provide the underlying framework for this paper are those outlined by Boehlje (1999) and King \& Venturini (2005). As agricultural economists, these researchers use the term "value chain" somewhat differently than a "values-based" supply chain. Boehlje defines a value chain as the "value-creating activities in the production-distribution process and the explicit structure of the linkages among these activities or processes" (p. 1032). "Value" for Boehlje refers to economic value, as opposed to social or environmental values. We suggest that additional social and environmental values are now emerging as important additions in farm-to-institution programs.

Both Boehlje and King and Venturini outline three types of "flows" that are important features of a value chain: product flow, financial flow, and information flow. In general, product flow refers to the physical movement of products and issues having to do with the supply of product - is it adequate, reliable, how is it aggregated, and where does it come from? Financial flow refers to payments for products, including issues such as prices, fees, and affordability. Information flow refers to the ways in which various participants in the chain communicate about values such as local, sustain- 
able, organic or any product attribute. It includes how transparent the process is all along the chain to the end consumer. It also refers to the negotiations and discussions that need to occur between the buyers, distributors, and farmers to set up a system that can work for everyone (sometimes referred to as transaction costs).

In our analysis, we will use the three types of flows (product, financial, and information) as organizing principles for describing our research results. By examining these flows across the supply chain, we can identify key insights that emerge throughout the system as opposed to within a single sector.

\section{Methodology}

Our study collected data from California supply chain participants with some national data included in the student survey. We used three research methods:

1. A national survey of college students' demand for environmentally sustainable food;

2. A survey of food service buyers in California colleges, universities, and teaching hospitals; and

3. In-depth interviews with actors in current farmto-institution distribution networks in California.

The next section provides a brief overview of each of these methods.

\section{The Survey of College Students}

A self-administered mail survey was sent to 2,000 randomly selected college students $(1,000$ from a U.S. population and 1,000 from a California population) in 2007. A slightly modified Dillman method was used to distribute the surveys (Dillman, 2000). We sent the students a letter announcing that the survey was coming, the survey with its cover letter and a US $\$ 1$ bill, a follow-up postcard, and a final reminder with a replacement survey. We used a tracking number to ensure we did not contact participants again once they completed the survey. Of the 2,000 surveys sent, 371 bounced back with bad addresses and 419 were returned. Only $54 \%$ of these, however, were college students; it appears the sample of names and addresses purchased from a marketing firm, U.S. Data Corporation, was inaccurate. Given the large non-college student sample, we estimated the response rate to be between $22 \%$ and $28 \% .^{2}$ Given this response rate, it is difficult to be completely confident the results extend to the entire population. The survey data was hand-entered into a Microsoft Access database and analyzed in SPSS. The surveys identified interest in and willingness to pay for food produced in an environmentally sustainable manner from small and midscale farms. It also compared the level of student interest in different values, as well as desired products.

\section{The Survey of Institutional Food Service Buyers}

All public and private four-year universities and teaching hospitals in the United States were included in the survey, as well as public two-year community colleges with enrollments of at least 10,000 students. Names of California university food service directors came from the National Association of College and University Food Services (NACUFS) membership list. This 2007 telephone survey of 99 food service buyers identified current purchasing practices, sourcing criteria, procurement practices, distribution infrastructure, administrative costs and requirements, packaging and other product preferences, as well as willingness to pay for food produced in an environmentally sustainable manner from small and midscale farms. The response rate was $100 \%$ for the universities and teaching hospitals, and $45 \%$ for the community colleges. Respondents included 14 managers in the University of California system, 23 in the California State University system, 23 private four-year institutions, 25 public community col-

\footnotetext{
${ }^{2}$ This estimated response rate assumes that $54 \%$ of the sample was actually college students (based on the actual response numbers). Thus, we assume that the number of college students sent the survey was 1,100 , that $54 \%$ of the bad addresses were college students (200) and that ultimately only 880 college students actually received the survey, resulting in a $25 \%$ response rate. If we take the $95 \%$ confidence interval around the breakdown of college students, the actual response rate is likely to be between $22 \%$ and $28 \%$.
} 
leges, and 14 teaching hospitals. In a few cases, managers for both residential and retail dining services at the same university were interviewed. Some findings are reported in Hardesty (2008). ${ }^{3}$

\section{The In-depth Interviews}

The overall objectives of the in-depth interviews were to (a) characterize the salient features of the distribution models in existing California farm-toinstitution programs, and (b) identify the key factors conducive to successful farm-to-institution programs. We selected interviewees in active farmto-institution programs based on our own contacts, the farm-to-college website, and snowball sampling. Face-to-face and phone interviews conducted in 2007 focused on how transactions were working, and the challenges and opportunities found in existing farm-to-institution programs. Data were collected from small and midscale California producers who sell to institutions, distributors who buy from such producers and sell to colleges and universities, and food service buyers who purchase local and sustainable produce. Usable data were collected from 17 farmers, 15 distributors and 16 food service buyers. These interviews elicited both quantitative data related to sales and qualitative data that generated nuanced understandings of terms, issues and procedures.

Responses to qualitative interview questions were recorded as narrative. In response to these questions, emerging themes or key words were identified, coded and then quantified. Data were reviewed by each research team member in order to ensure consistency in the coding system. Additionally, the nature of concepts associated with the key words was analyzed and "key word" responses were combined into larger categories and analyzed in relation to overall benefits and challenges. Finally, similarities, differences, and patterns were

\footnotetext{
${ }^{3}$ Hardesty (2008) discusses the prospects for marketing locally grown produce to colleges and universities based on only the institutional food service perspective. Results are described for an agricultural economics audience using a transaction costs framework and logit analysis. This paper, in contrast, describes results along with the other surveys and interviews in this study and interprets them for practitioners in farm-toinstitution programs.
}

analyzed across the three groups.

The research team worked together to design these three separate studies. Each study was conducted and the data analyzed by a subset of the overall team. Findings from each study were discussed and interpreted both in small groups and with the research group as a whole.

\section{Results}

We report our findings below, organized by the three types of flows: product flow, financial flow, and information flow. We apply these concepts to the emerging farm-to-institution markets and describe the implications for farmers, distributors, buyers, and consumers. Our studies provided new insights on how these flows function in farm-toinstitution values-based supply chains.

\section{Product Flows}

We began by creating a visual map of farm-toinstitution products flows - identifying all the players involved, including both conventional and values-based players. Figure 1 below depicts the flows of fresh produce from farm to fork. This simplified diagram does not include every type of participant one might see in a comprehensive distribution model. We focused on the entities that appeared in our values-based supply chains.

Fresh produce flows from farms (left) to institutional buyers and their consumers (right), through various distributing entities. As the arrows show, sometimes purchases are direct from farmers; most often they go through packer/shippers (green triangles) and/or some type of distributor (blue squares). The large black arrow indicates that most of the fresh produce purchased by college and university food service buyers comes from broadline distributors (the largest square) or their subsidiaries. The smallest distributors we encountered (turquoise squares) are emerging entities, often associated with nonprofit organizations that service mainly local food markets, schools, and other institutions interested in buying locally. We also noted one new entity - a farmers' market broker - who facilitates sales from farmers who come to 


\section{Figure 1. Supply Chain for Farm-to-Institution Programs}

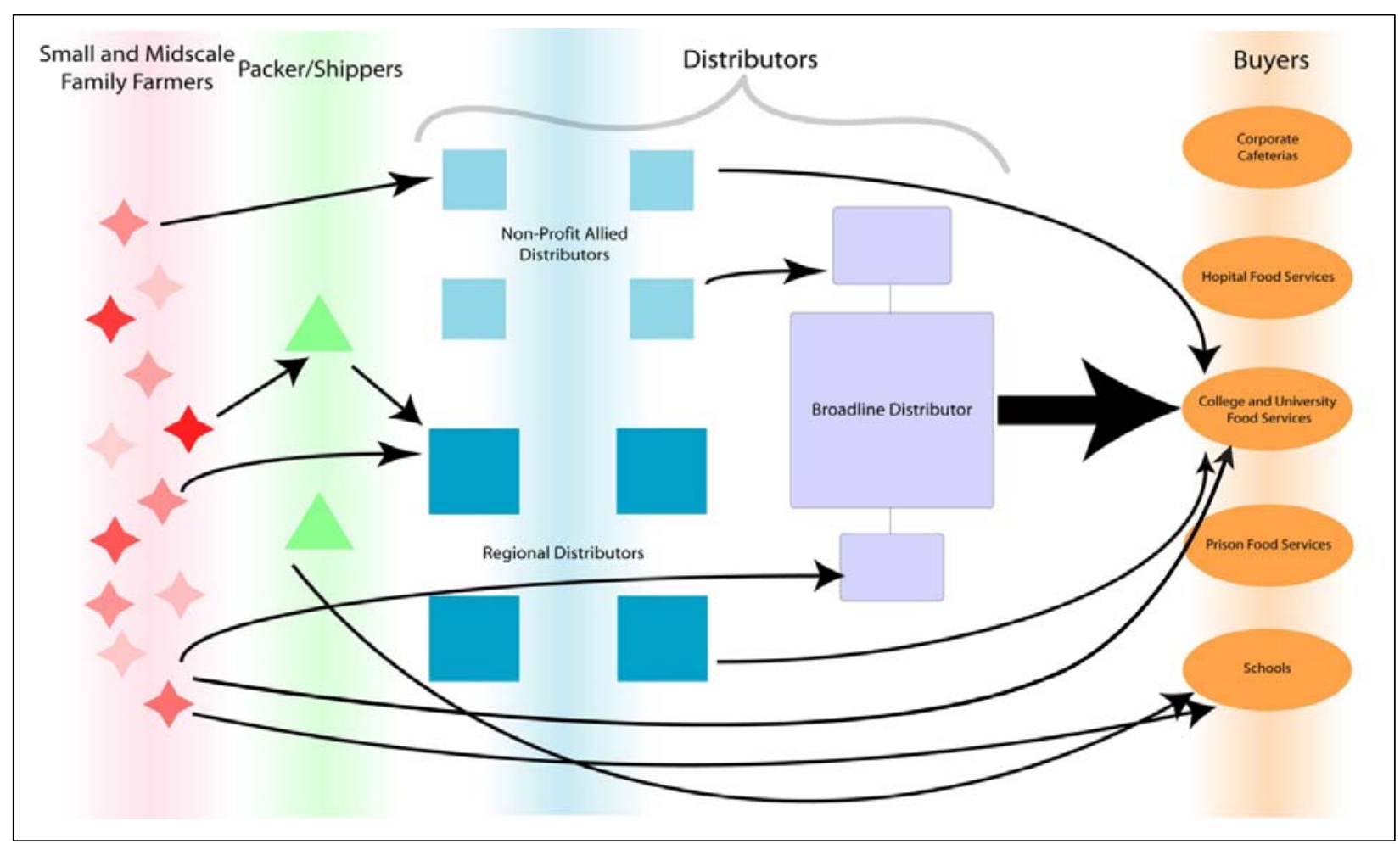

a farmers' market to institutional food service buyers for schools and other institutions. Our investigation of product flow in the distribution system shows us that while broadline distributors tend to dominate the market, alternative distribution networks are emerging in response to consumers' desire to confirm that they are buying from local producers.

\section{What We Know About Product Flows from Multiple Perspectives}

Here we explore the nature of product flows among the firms (e.g. farms, distributors, food service operations) in the system. More specifically, we identify where firms get their food, what factors are important for participating in a farm-toinstitution value chain, and what barriers exist to participation. Each stakeholder group is described in turn.

\section{Food service buyers}

Data from the food service buyer surveys and indepth interviews found that food service buyers in colleges with locally grown produce programs
Figure 2. Percentage of Produce Purchased by Food Service Buyers From Different Sources (colors follow from figure 1)



routinely purchased their produce from multiple suppliers. Broadline distributors and regional produce distributors were the primary sources (see figure 2), while direct purchases and nonprofit 
allied distributors ${ }^{4}$ represented only $12 \%$ of the overall distribution infrastructure.

When comparing buyers with and without local programs, data confirmed that, in general, buyers with local buying programs diversified their sources more than those without such programs. For example, a third of those with a local buying program sourced from three or more distributors, as compared with $12 \%$ of those without. On the other hand, $51 \%$ of those without a local buying

Table 1. Number of Produce Distributors by Local Buying Program Status

\begin{tabular}{lccc}
\hline & \multicolumn{3}{c}{$\begin{array}{c}\text { Number of Produce Distributors } \\
\text { Buyers Use }\end{array}$} \\
\cline { 2 - 4 } & 1 & 2 & 3 or more \\
\hline $\begin{array}{l}\text { No Local Buying } \\
\text { Program }\end{array}$ & $25(51 \%)$ & $18(37 \%)$ & $6(12 \%)$ \\
$\begin{array}{l}\text { With Local Buying } \\
\text { Program }\end{array}$ & $3(11 \%)$ & $15(54 \%)$ & $10(36 \%)$ \\
\hline
\end{tabular}

Figure 3. Food Service Buyers' Rating of Various Criteria for Local Produce Suppliers: \% Rating Each Criterion as Very or Extremely Important

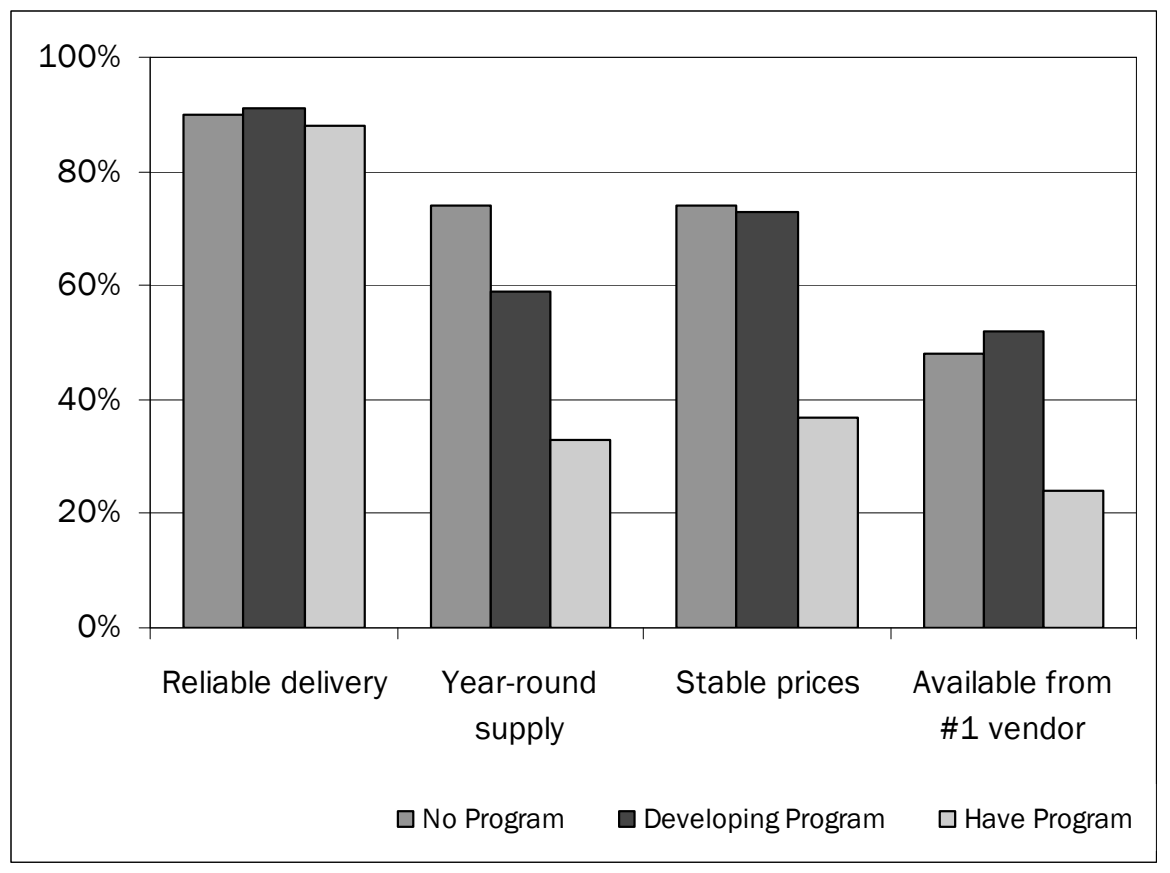

${ }^{4}$ Those distributors associated with nonprofit organizations that run a distribution business. program sourced from only one distributor as compared with $11 \%$ of those with such a program. See table 1.

Buyers considered several criteria when selecting produce suppliers (see figure 3). Top criteria were reliable delivery, a ready year-round supply, and availability of local produce from their primary vendor. Stable prices were also important, particularly for buyers without a local program. The main point here is that buyers already participating in farm-to-institution programs were just as concerned about reliability of delivery, but were much less concerned with the other three criteria. This suggests either that barriers diminished in importance once the relationships and basic arrangements were established, or that those most interested in implementing value-based supply chains were more flexible to begin with.

\section{Distributors}

For distributors, the form in which they received food was an important criterion for working with smaller, local farmers. Processing requirements showed up as the second most important factor after bidding (to be discussed in Financial Flows, below). Here, distributors were responding to their customers' needs, that is, to food service buyers' expectation that products be at least minimally processed.

Payment arrangements and insurance were considered less of a barrier for distributors than we expected. Distributors did not see small farmers' lack of liability insurance as a barrier, since distributors already had the insurance coverage required by 
their institutional customers. When asked more broadly about the challenges of providing locally grown produce to institutions, distributors more prominently identified the delivery system. They mentioned "getting the product to [the institution] in a timely fashion" and "reliability in transporting produce" as definite challenges. Other challenges they reported included general administrative requirements - paperwork and the ordering system - and matching supply with demand, both in volume and quality.

\section{Farmers}

For farmers, as for food service buyers, having a dependable market is important. However, the most significant barrier to efficient product flow was the delivery system. Challenges related to the delivery system include consistency and reliability of orders and the means of getting the products to the end user. Farmers were also concerned about their ability to provide a consistent supply in the quantities needed by the institutions. Climatic conditions often prohibit farmers from being yearround suppliers. Because of the likelihood of unexpected events, such as sudden or extreme weather patterns, farmers were not always sure they could meet the demand. Aggregation with other growers was a solution for some small and midscale growers. Some of the nonprofit allied distributors, in their efforts to support small farms and to promote local procurement, helped to aggregate products from small and midscale growers. When these negotiations worked well, trust and positive relationships were reinforced, and the values attached to "local produce" were similarly reinforced.

\section{Financial Flows}

Financial flows, such as cost and price considerations and payments to suppliers, are ongoing issues for all parties, although surprisingly cost is not as important as other factors. This is supported by the data showing that local buying programs are growing in number and popularity, despite higher costs.

\section{Food service buyers}

The survey of food service managers at colleges in
California found that $50 \%$ of those interviewed either had a program for locally grown produce or were developing one. The average food service budget among colleges with such a program was $\$ 3.5$ million (range $\$ 200,000$ to $\$ 12$ million). Their produce purchases averaged $\$ 527,000$ (range $\$ 50,000$ to $\$ 1.5$ million). On average, $28 \%$ of their produce purchases were locally grown (range 3\% to $70 \%$ ). The premiums they paid for local produce ranged from $0 \%$ to $35 \%$, and averaged $13 \%$.

During the in-depth interviews, food service buyers estimated that they could increase their purchases from local growers from an average of $21 \%$ to an average of $38 \%$ of their overall produce budget. In fact, the average increase could be higher, because these figures assume that the buyers who did not provide data would not increase their purchases at all. Sixty-three percent of all food-service buyers reported price premiums for local produce. Of those reporting, the average was $63 \%$ higher for local produce and $25 \%$ higher for organic.

Although these premiums seem sizable, all of the food service buyers said that the higher prices were not a problem because, so far, the amount they were buying was a relatively small proportion of their overall purchasing. Therefore, in most cases, they were absorbing the increase within their overall budgets. In some cases (such as hospital cafeterias and casinos), they were passing it on to customers.

\section{Distributors}

Distributors were more mixed in their opinions about the cost of local produce: $40 \%$ thought that there was no price difference, while $33 \%$ thought that locally grown produce was more expensive. Only $7 \%$ thought that local produce was less expensive.

Variation in responses may have depended on which products a distributor was comparing during which seasons. Produce prices fluctuate a fair amount, and certain products are more expensive at certain times of the year. On a related note, distributors did mark up their local produce, but the mark-up did not differ much from mark-ups for their conventional produce. The average mark- 
up was $25 \%$ and fluctuated depending on the negotiated terms with the customer.

\section{Farmers}

From the farmers' perspective, a very limited proportion of their revenues in 2006 - approximately $2.5 \%$ on average - was attributable to farm-toinstitution accounts. However, the range was large (from less than $1 \%$ to $55 \%$ ), with the smallest farmers tending to have the largest percentage of sales going to institutional markets. The larger farmers already have well-established, profitable outlets for their products and may be less interested in selling more to institutions.

\section{Student Consumers}

We asked students whether they would pay more for food with sustainability values. Student willingness to pay higher prices is of concern to dining hall managers, who might have to raise prices to cover the costs of sustainably produced food. Over $40 \%$ of students surveyed said they are willing to pay more for food that is organic, local, produced in accordance with living wage guidelines, or sustainably produced (at least US $\$ .50$ more for a

Table 2. Frequency of Student Purchases of Fair Trade, Local or Organic Foods

\begin{tabular}{lccc}
\hline & $\begin{array}{c}\text { Fair Trade } \\
(n=218)\end{array}$ & $\begin{array}{c}\text { Organic } \\
(n=216)\end{array}$ & $\begin{array}{c}\text { Local } \\
(n=219)\end{array}$ \\
\hline At least weekly & $8 \%$ & $11 \%$ & $12 \%$ \\
At least monthly & $11 \%$ & $32 \%$ & $34 \%$ \\
At least once a year & $7 \%$ & $23 \%$ & $19 \%$ \\
Never/Don't know & $41 \%$ & $31 \%$ & $31 \%$ \\
I've never heard of this term & $33 \%$ & $3 \%$ & $4 \%$ \\
\hline
\end{tabular}

Table 3. Importance of Various Attributes to Food Service Managers and Customers

\begin{tabular}{lcc}
\hline \multirow{2}{*}{ Attribute } & \multicolumn{2}{c}{ Importance to Food-service Manager } \\
\cline { 2 - 3 } & Average Rating & \% Rating 6 or 7 \\
\hline Inexpensively priced & 5.6 & $58.1 \%$ \\
Locally grown & 4.9 & $47.3 \%$ \\
Sustainably produced & 4.6 & $39.7 \%$ \\
Grown by small or midscale & 3.8 & $29.1 \%$ \\
producer & & \\
Organic & 3.5 & $18.9 \%$ \\
\hline
\end{tabular}

salad originally costing US\$3.50). Interest in small farms was lower compared to the other qualities; however - over $40 \%$ of the students said they would not pay a premium for produce grown on small farms.

Since responses to questions about "willingness to pay" are often overinflated, the student survey attempted to assess what people might actually purchase. To get at an approximation of what their actual behavior might be, we asked the students about the frequency with which they have purchased organic, local, and fair trade foods. Student responses on their purchasing patterns indicated that a sizable proportion of students may support organic and local foods on campus. As table 2 shows, a fairly large percentage of students buy organic and local food somewhat regularly (at least monthly), and an additional $11-12 \%$ purchase those foods at least weekly.

\section{Information Flows}

Information flows may be the most important component of emerging values-based supply chains. While price information is easily conveyed throughout traditional supply chains, information regarding values such as sustainability, fair labor, or use of local products is not readily available to buyers at different points in a supply chain. In this section, we explore the values in which people are most interested. We also explore the advantages of "local" as a way of identifying useful communication strategies. Efficiency, clarity, and transparency of communication are important elements of the information flow.

\section{Food service buyers}

Food service buyers indicated that they had relatively strong interest in environmental and social values (see table 3). Although they rated price (on a 1 to 7 Likert scale) as the most important attribute to them for the 
produce they purchase for their dining operations, "locally grown" and "sustainably produced" were also very important, with average attribute ratings of 4.9 and 4.6, respectively. Organic was the lowest rated among the five attributes.

\section{Distributors}

In the in-depth interviews, distributors identified values beyond the quality of the produce in working with local growers. Developing personal relationships was highly valued. According to one distributor, "You are talking to a person, not a corporation. You know who they are, can walk into the farm and say hello. I have many farmers that grow specifically for us. They are more agile. You can brainstorm together on marketing and do something different more easily." New and different kinds of conversations are taking place in the business transactions that involve local farmers.

As a group, distributors identified bidding requirements as the most challenging factor they face in working with local farmers. These negotiations include several factors in addition to prices; they are based on minimum acceptable standards as defined by the buyer's operational requirements. In this context, they are typically based on price, volume, availability, and food safety. Negotiation requires that both parties understand and support the product attributes and accompanying values they wish to be conveyed through the system. This requires information exchange. Values such as "sustainably grown" and "local" have not typically been included in negotiations. Despite this, distributors have managed to work within the constraints of the system by coming up with creative solutions, sometimes in collaboration with growers.

\section{Farmers}

Even though the farmers we interviewed were eager to establish new business partnerships, most were also concerned about paperwork and institutional requirements such as permits and insurance. They felt that having to go out to bid can prohibit institutional purchasers from buying local if this attribute is not specified as a criterion in the bid. Other concerns were that requirements for permits can be cost-prohibitive, and that requirements relating to liability and insurance, health inspections, and audits may be difficult to comply with. Farmers we interviewed believed that the regulators need to take measures to streamline the bureaucracy and reduce costs for growers.

With challenges such as these, we wanted to know the value that each sector placed on local and sustainable production and procurement. Several advantages of working with small to midscale local farmers rose to the top in the interviews with different sets of actors. While there was broad agreement on the values themselves, each group assigned different priorities to them. Quality of the produce and supporting the local economy were particularly important for food service buyers and distributors; creating community connections was more important for distributors and farmers; decreasing the carbon footprint was least important to all, especially for distributors and farmers. However, taken together, these advantages form the rationale for specific changes in order to increase farm-to-institution procurement.

\section{Student Consumers}

Communicating about demand is part of information flow. Changing procurement practices on college campuses can be prompted or encouraged by knowing if there is support for these changes. In order to determine potential demand for food with sustainability qualities, we asked students what kinds of food they wanted to have their colleges provide, and to rate these qualities on a 7 point scale, with 7 being very important and 1 being very unimportant.

In this question, we asked about food qualities that research shows to be important to consumers generally, such as convenience, safety, and price, as well as about qualities related to sustainability. We also hoped that the comparison would keep people from rating the sustainability criteria in an arbitrary way.

As figure 4 shows, students are equally interested in the food qualities that conventionally are valued as most important in other consumer research: safety, 
Figure 4. Percentage of Students Who Rated Certain Qualities as Important (top 2 out of 7 on the rating scale) $(N=219)$

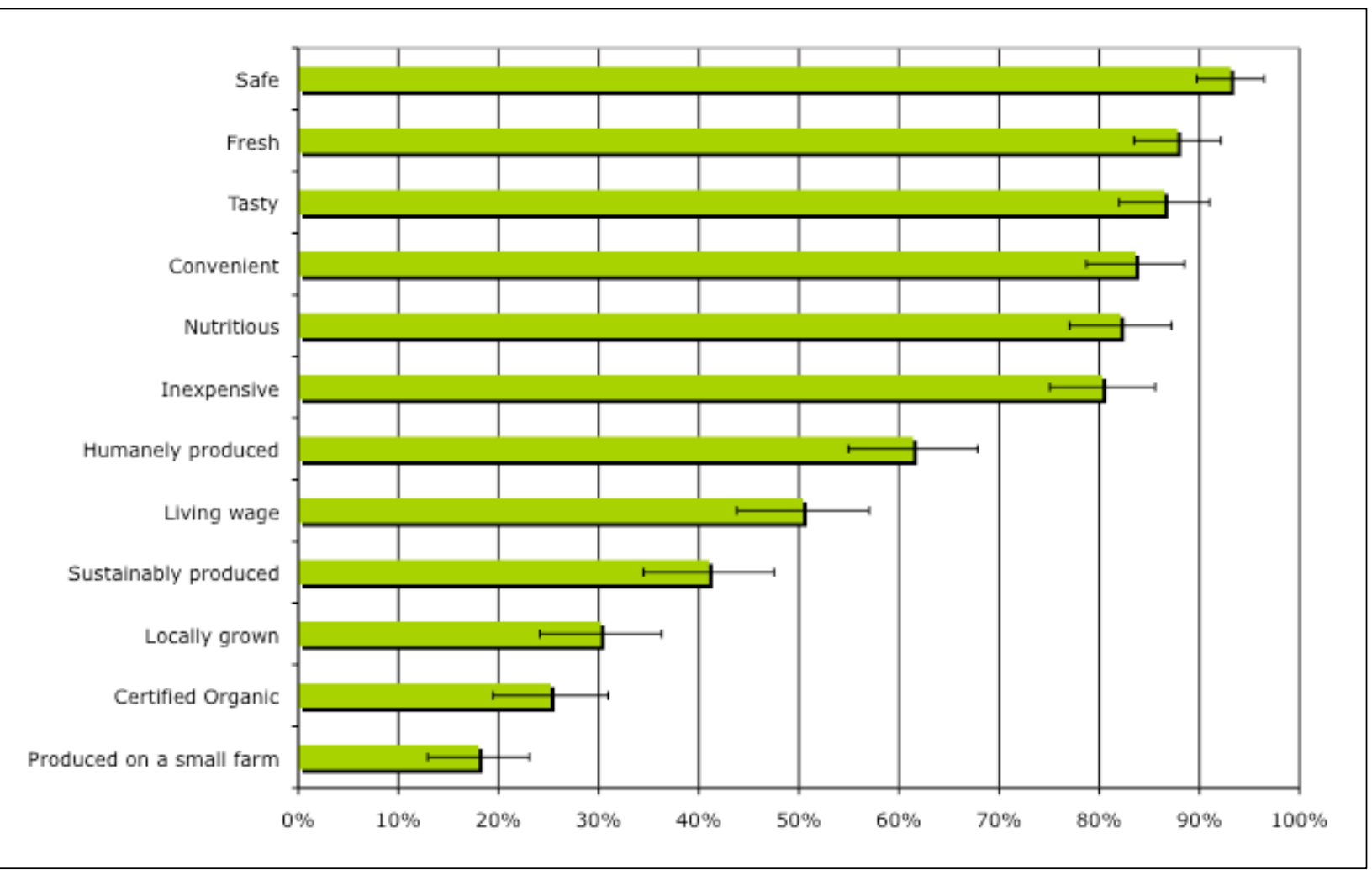

freshness, taste, convenience, nutrition, and price. These qualities have an impact on the person consuming the food. Also, as expected, the sustainability-related criteria — criteria that are more socially oriented and have a less immediate impact on the person - are less frequently cited as being important for their dining service to provide. Next highly ranked are values that have to do with the welfare of others - food that is humanely produced and where a living wage is paid to workers. Interestingly, the three lowest ratings are for "locally grown," "certified organic," and "produced on a small farm," which are the criteria most often promoted in farm-toinstitution programs.

Understanding what people want to know about their food and how they want to learn about it is important for developing education on sustainable food issues. To this end, students were asked to rate how they would most like to get information on food issues. They were directed to select up to four items (table 4). The two most preferred methods, product labels $(62 \%)$ and

Table 4. Outreach Strategies Students Prefer To Get More Information About Their Food $(N=224)$

\begin{tabular}{lc}
\hline $\begin{array}{l}\text { How would you like to obtain more } \\
\text { information about your food? }\end{array}$ & $\begin{array}{c}\text { Percentage choosing } \\
\text { among top 4 items }\end{array}$ \\
\hline $\begin{array}{l}\text { Product labels } \\
\text { Brochure, table tent, or display located } \\
\text { where you purchase or eat your food }\end{array}$ & $52.2 \%$ \\
Newspapers or magazine articles/books & $48.5 \%$ \\
Web pages/the internet & $46.4 \%$ \\
Television program/videotape/DVD & $27.0 \%$ \\
Tours of farms and/or processing plants & $20.5 \%$ \\
Talking to seller/farmer & $11.9 \%$ \\
Radio & $10.2 \%$ \\
Classroom lecture and/or guest speaker & $10.0 \%$ \\
Campus event or presentation & $9.4 \%$ \\
Study group & $3.5 \%$ \\
\hline
\end{tabular}


brochures (51\%), are information sources provided where people choose their food. This implies that education efforts in dining halls and cafeterias are an excellent option. The next most frequently chosen methods - print (49\%) and the Internet $(46 \%)$ - are also viable as education outlets on food system issues for college students. Many institutional dining services have active websites where information about sustainable food systems could be posted. Twenty-seven percent of the students were interested in audiovisual methods, and $20 \%$ were interested in farm tours.

\section{Discussion}

Integrating perspectives from several types of stakeholders in values-based supply chains enriches our picture of how these chains function and what is needed to improve upon them or expand them further. There are no simple answers. Based on our study's results, we offer insights and lessons for practitioners on product flows, financial flows, and information flows.

\section{Insights on Product Flows}

Creating and continuing farm-to-institution efforts require getting the products with the desired values through the food chain. This product flow involves all stakeholders, and particularly the food service buyers, distributors, and producers, since they are most involved in providing products with specific values for the customers at the end of the chain.

One notable finding is that all stakeholders had to balance the "sustainability values" (local, sustainable, organic, fair trade) with the more conventional market values (inexpensive, convenient, efficient). There is no clear "line in the sand" about when and how buyers, distributors, or farmers will support values-based supply chains and when they do not. For example, buyers were often willing to experiment with purchasing more local or sustainable products, especially if their administration or company supported these decisions. Overall costs always have to be taken into consideration, however. Other factors that we did not measure (e.g., college budget cuts) may change the balance. The students' balancing act was apparent in their responses regarding all the qualities in food that they want their college to provide, which included those of being both inexpensive and sustainable.

Another aspect of creating a successful product flow is having flexibility and creativity in pivotal locations in the food chain. Buyers, in particular, can help "pull" values-based products through the system. In the in-depth interviews, we found that these buyers and the distributors they worked with were willing to make accommodations and try new products and procedures, even if it was not a smooth process in the beginning. They were not afraid of using multiple distribution channels simultaneously to get products they wanted. Even though finding new suppliers and distributors might be messier, they were willing to find a way to make it happen. They were less concerned with efficient logistics and more concerned with a broader vision of a more "sustainable, regional" food system.

Diversity, in many aspects, was another theme associated with successful products flows. For the farmers, having a diverse crop mix and using season extension methods to lengthen their marketing season allows growers to meet buyers' needs for more of the year. It can also apply to having a diversity of farm sizes as part of an aggregated consortium of farmers who supply the chain. For the nonprofit allied and small produce distributors in particular, the farmer collaborative worked much better when it was anchored by several midscale to large farms who could provide larger volumes to buyers when needed. In other words, having a diversity of scale incorporated into distribution entities was critical to their success.

Small and midscale growers could improve their participation in such values-based supply chains when they have opportunities for planning ahead with food service managers, perhaps creating forward contracts (in which buyer and seller agree today on a price for future purchases of a particular product). The bidding process, although a barrier in some instances, could also be seen as an opportunity for opening new markets, if the request for proposals or bidding language names the values for which these chains are known. 


\section{Insights on Financial Flows}

Although prices and costs were clearly on the minds of all stakeholders in the supply chain and everyone wanted a good deal, food service buyers, distributors, and farmers were all willing to adapt. For example, fully $50 \%$ of food service buyers were either part of a local buying program or initiating one, despite the fact that they admitted it would probably be more expensive. Those who were already participating in programs promoting values-based supply chains seemed more willing to experiment. They often found other ways within their budgets to cut costs so they could absorb additional costs of the local and/or sustainable buying programs. Those who were part of these values-based supply chains were generally more willing to optimize costs throughout the chain rather than maximize their own economic benefits. The focus is on "optimality" vs. "efficiency" to achieve welfare for all parties. Those who were not part of such programs generally felt that price was a barrier.

For student consumers, current purchases of valuebased food products, whether on campus or off, were relatively low. However, about a third of students surveyed purchased organic or local products at least monthly, suggesting there may be room for growth. At least $50 \%$ of students surveyed claimed they would pay US $\$ .25$ more for a US $\$ 3.50 \mathrm{salad}$ (a 7\% premium) with values of organic, local or sustainable attached.

Among the food service buyers, those who were either developing or had a buying program for local produce had a greater willingness to pay for each of the production attributes. Expanding the market for sustainable food therefore depends on increasing the interest of institutions without local buying programs regarding the benefits of sustainability attributes.

When we look at the whole supply chain together, it appears that many participants throughout the supply chain are willing to experiment with purchasing foods with sustainability values even if it costs more in the beginning. Given that the context is a university or college campus setting where these values are discussed in classes and in professional food service settings, this may be one amenable market to start in when thinking about how to ramp up these values-based supply chains.

\section{Insights on Information Flows}

Although the values of "local," "sustainable," "organic," and "small farms," which are often associated with local buying programs in colleges and universities, are apparently growing in importance, they are still ranked below "the BIG 6" of safe, fresh, tasty, nutritious, inexpensive, and convenient, at least for college students. Some of the demand for pulling these value-laden products through the system comes from students. Institutional food service buyers generate most of the demand. Food service buyers explained that entering freshman students need to be educated every year about these values. At the beginning of the year, many are just learning about the concepts. By the end of the year, they are beginning to select more foods associated with local buying programs. Our survey responses from students seem to echo this point (although freshmen were a very small segment of the sample).

Another similar education opportunity is to ensure that each segment of the value chain understands the priority food-related values of those in the other parts of the value chain. As our data shows, the sellers' perceptions of their customers' interests did not always match what the research found about their customers' interests. Food service buyers (directors, chefs) hear about these values from their professional organizations, the leadership of their food service management companies, or top administrators of their colleges and universities. Many had been encouraged by management to try out more local, sustainable products and programs. In a few universities, students were in the vanguard, voicing their support for these values and asking for them to be embedded in food choices. This provided an additional supportive context in which buyers made procurement decisions. Student voices were much more effective when organized by student groups and leaders and 
when requests were made in a highly visible manner. As educational institutions, colleges, universities, and even teaching hospitals have a mandate to educate. In some cases, students and faculty used this as an opportunity to share information on multiple levels - among students, food service buyers, distributors, and farmers. In these instances, students were interested in changing campus policies to embed these values in future food service procurement practices.

Information exchange among buyers, distributors, and farmers most often was included in "transaction costs," including all the time and effort needed to negotiate new logistics and information systems associated with obtaining sustainable, local, or organic products from new suppliers or systems. For some, this additional information exchange became a barrier. For others, it became a challenge to be overcome and to learn from. The majority of interviewees from the case studies (who were already part of values-based supply chains) said that they welcomed this opportunity to learn more about other participants in the supply chain. In fact, several food service buyers had gone on farm tours with those growers who supplied their food. Not only did they learn about how the food was grown and delivered, they also gained knowledge about the larger economic, environmental, or structural issues such as consolidation in the food system, the disappearance of land, and the struggle to compete against very large-scale producers in the United States and abroad. Producers learned about the struggles that food service buyers have in getting a reliable flow of supplies of these products and marketing them to their customers.

As a result of meetings, workshops, tours, phone calls, and ongoing conversations over time, all parties could come to agreements about how to handle logistical challenges. Moreover, they began to form relationships with each other. This trustbuilding is essential to forging new business connections and new values-based procurement practices. Rarely were things perfect the first few times sales and deliveries were made. It took time to work out the details. Ongoing and open communication was essential to build trust and come up with creative solutions that met all parties' needs.

\section{Education Is the Key}

For future values-based supply chains to grow and thrive, our results point to education as the key ingredient. Education is needed at each level among the participants in that particular sector. Most students need — and many want - more education about the food system and what is entailed in getting food from field to table. Food service personnel need information about finding new sources of regional, sustainable food, and about initiating new types of bidding proposals or forward contracts that embed these values as part of the expectations or criteria in addition to price. Growers and distributors need education about new mechanisms for aggregating and processing regional products and finding ways to tell the farmers' story so buyers and consumers will know what they are paying for - especially if they agree to pay more. Producers need education about strategies for preprocessing product and reaching out to new institutional buyers.

Educational entities - colleges, universities, community colleges, culinary programs, cooperative extension services, and the media - also have roles to play. They can be the vehicles that provide as much information as possible to the public about the functioning of the food system. They can also share the possibilities for environmental, economic, and social sustainability that could occur with new values-based supply chains. The risks and challenges need to be aired as well. If practitioners, researchers, and others want to see these new values-based supply chains succeed, mistakes and problems as well as successes need to be shared.

\section{Limitations of Research}

Although this study provides valuable information, there are several limitations that need to be recognized. The student survey had a fairly low response rate due largely to a faulty sample provided by the mailing list firm used in this study. Given the smaller sample, the results may not be generalizable to the whole population. The number of in-depth interviews of farm-to-institution program partici- 
pants (farmers, distributors, and food service buyers) was also small, so results also may not be entirely generalizable. We did choose survey questions that were similar to those in the food service survey so that we could compare responses. We found that responses generally agreed with each other, supporting results of both.

Also, this study was conducted mostly in California, although some student responses were from outside California. The year-round growing season and existence of more farm-to-institution programs than in other regions of the country may have suggested more options than can actually work in other places. However, we expect that many of the results here can also be adapted by other regions to take into account their unique circumstances.

Our study focused on the values-based supply chains for produce, as opposed to meat, grains, or dairy. We found that, at least in California, fruits and vegetables were the type of food most food service buyers started with when they considered buying regionally. There was more activity in the produce sector, so this area seemed most appropriate to study first.

Future research involving the entire supply chain should include larger and more representative samples of students, farmers, and distributors. In addition, it may make sense to select cases from diverse places with different climates, so that comparisons on the importance of various constraints and opportunities might be made across regions.

\section{Conclusion}

Farm-to-institution programs provide a rich environment in which to explore emerging valuesbased supply chains. Results from interviews and surveys throughout the supply chain, from farm to fork, provide a nuanced and comprehensive picture of challenges and opportunities required to strengthen and ramp up these systems. Using the theoretical constructs from the supply chain literature of product flows, financial flows, and information flows, we highlighted key issues of various participants in the supply chain. Information flows are perhaps the most important area for future attention. Interviewees and respondents were most excited about strengthening information flows and building relationships that would allow all parties to build trust over time. Educational institutions and the media can support these values-based supply chains by becoming the vehicles for ongoing exchange of information among supply chain partners and the public.

\section{Acknowledgements}

The authors would like to thank our project advisors, all located in California: Scott Berlin, Director of Dining Services, UC Santa Cruz; James Boushka, Sodexho, UC Davis; Tim Galarneau, UC Santa Cruz; Lynn Garske, Kaiser Permanente; Blong Lee, Fresno County Economic Opportunities Commission; Brett Melone, Agriculture and Land Based Training Association, Salinas; Eric Montell, Stanford Dining, Stanford University; Pete Price, consultant with Community Alliance with Family Farmers; and Paul Tarantino, FreshPoint San Francisco. We also thank colleagues at UC Davis, UC Santa Cruz, and the Community Alliance with Family Farmers, who provided important research and outreach support for this project: Gwendolyn Keith, UC Santa Cruz; Tracy Perkins, UC Davis; Aslihan Arslan, UC Davis; and Aliza Wasserman, formerly with the Community Alliance with Family Farmers.

\section{References}

Bloom, J. D., \& Hinrichs, C. C. (2010). Moving local food through conventional food system infrastructure: Value chain framework comparisons and insights. Renewable Agriculture and Food Systems, 26(1): 13-23. http://dx.doi.org/10.1017/ $\underline{\mathrm{S} 1742170510000384}$

Boehlje, M. (1999). Structural changes in the agricultural industries: How do we measure, analyze and understand them? American Journal of Agricultural Economics, 81(5): 1028-1041. http://dx.doi.org/ $10.2307 / 1244080$

Community Food Security Coalition. Farm to College. http://www.farmtocollege.org/survey\#profiles 
Dillman, D. A. (2000). Mail and Internet surveys-The tailored design method. New York, NY: John Wiley \& Sons, Inc.

Gereffi, G., Lee, J., \& Christian, M. (2009). US-based food and agricultural value chains and their relevance to healthy diets. Journal of Hunger and Environmental Nutrition, 4(4): 357-374. http://dx.doi.org/10.1080/19320240903321276

Gregoire, M. B., Arendt, S. W., \& Strohbehn, C. H. (2005, February). Iowa producers' perceived benefits and obstacles in marketing to local restaurants and institutional foodservice operations. Journal of Extension, 43(1), \#1R1B1.

Gregoire, M. B., \& Strohbehn, C. (2002, Spring). Benefits and obstacles to purchasing food from local growers and producers. Journal of Child Nutrition \& Management, 25(1). Available at http://docs.schoolnutrition.org/newsroom/jcnm/

Gregoire, M. B., Strohbehn, C., Huss, J., Huber, G., Karp, R., \& Klien, S. (2000). Local food connections: From farms to schools. (Pamphlet \#: PM1853A). Ames, IA: Iowa State University Extension. Available at http://www.extension.iastate.edu/ Publications/PM1853A.pdf

Hardesty, S. (2008). The growing role of local food markets. American Journal of Agricultural Economics, 90(5): 1289-1295. http://dx.doi.org/10.1111/ j.1467-8276.2008.01219.x

Hawkes, C. (2009). Identifying innovative interventions to promote healthy eating using consumptionoriented food supply chain analysis. Journal of Hunger and Environmental Nutrition, 4:336-356. http://dx.doi.org/10.1080/19320240903321243

Izumi, B. T., Alaimo, K., \& Hamm, M. W. (2010). Farm to school programs: Perspectives of school food service professionals. Journal of Nutrition Education and Behavior, 42(2): 83-91. http://dx.doi.org/ 10.1016/j.jneb.2008.09.003

Izumi, B. T., Wright, D. W., \& Hamm, M. W. (2009). Farm to school programs: Exploring the role of regionally-based food distributors in alternative agrifood networks. Agriculture and Human Values, 27(3): 335-350. http://dx.doi.org/10.1007/s10460009-9221-x

King, R. P., \& Venturini, L. (2005). Demand for quality drives changes in food supply chains. In A. Regmi \& M. Gehlhar (Eds.), New directions in global food markets (Chapter 2) (USDA Economic Research Service Agriculture Information Bulletin No. AIB794). Retrieved from http://ers.usda.gov/ publications/aib794/aib794d.pdf

Murray, S. C. (2005). A survey of farm-to-college programs: History, characteristics and student involvement (Unpublished master's thesis). College of Forest Resources, University of Washington, Seattle, Washington.

Starr, A., Card, A., Benepe, C., Auld, G., Lamm, D., Smith, K., \& Wilken, K. (2003). Sustaining local agriculture: Barriers and opportunities to direct marketing between farms and restaurants in Colorado. Agriculture and Human V alues, 20(3): 301321. http://dx.doi.org/10.1023/A:1026169122326

Stevenson, G. W., \& Pirog, R. (2008). Values-based supply chains: Strategies for agrifood enterprises of the middle. In T. A. Lyson, G. W. Stevenson, \& R. Welsh (Eds.), Food and the mid-level farm (pp. 119143). Cambridge, MA: MIT Press.

Vogt, R., \& Kaiser, L. (2008). Still a time to act: A review of institutional marketing of regionallygrown food. Agriculture and Human V alues, 25(2): 241-255. http://dx.doi.org/10.1007/s10460-007$\underline{\text { 9106-9 }}$ 